Anais da Academia Brasileira de Ciências (2013) 85(1): 431-435

(Annals of the Brazilian Academy of Sciences)

Printed version ISSN 0001-3765 / Online version ISSN 1678-2690

www.scielo.br/aabc

\title{
The Low Academic Profile of Brazilian Economists
}

\author{
ROGERIO MENEGHINI \\ SciELO, Scientific Electronic Library Online, \\ Rua Machado Bitencourt, 430, Vila Clementino, 04044-001 São Paulo, SP, Brasil \\ Manuscript received on June 5, 2012; accepted for publication on November 13, 2012
}

\begin{abstract}
The worldwide prestige of economists in the lay media lies significantly higher than scientists and academics from other fields of expertise. Brazil is not an exception as well.

A point that calls attention to this fact is that the most prestigious international economists, who are frequently present in the lay media, are also distinguished in the academic environment. The lay prestige may be measured by their presence in the media and by surveys of public opinion, whereas academic prestige may be evaluated using database indicators of publications and citations of academic articles. One indicator that became frequently used is the h-index, measuring publications and citations simultaneously. A relevant finding regarding international economists is that both lay prestige and academic prestige are high and, apparently, mutually dependent. Among Brazilian economists, lay prestige is not accompanied by academic prestige. This last one is significantly low, even though doctorate studies in international universities of excellence are commonplace in these economists' curricula. The data point to a low intensity of academic life in Brazilian economics schools.
\end{abstract}

Key words: scientific assessment, h-index, Brazilian economists, academic prestige, lay prestige.

\section{INTRODUCTION}

Economics has been an always-present and attractive theme in international media. Its scenario is often linked to politics or to the market. Important events related to Economics have had enormous repercussions on recent history. At the international level the oil crisis of 1973-1974 and the global crunch that began in 2008 and extended until today has received large amounts of attention in the media. At the Brazilian level, news of the battles against inflation and the establishment of the "Plano Real" in 1994 had been followed as eagerly as sport events.

In the handling of news in Economics the theories, laws and jargon are inevitable. It is not an overstatement that in no other area of science

E-mail: rogerio.meneghini@scielo.org the media has exerted such awareness among the laymen. Regardless of certain incredulity as to the acceptance of Economics as a science (Pollock 2010), even more after the "unpredictable" crisis of 2008, the debate among the supporters of different currents persists, followed by the laymen's interest in the outcomes for their country and in the better options for their investments.

\section{RESULTS AND DISCUSSION}

It is noteworthy how present in news pieces and media interviews the economists are; not only those with academic credentials, but also the autodidacts that obtain dexterity in interacting with laymen. In Brazil, the Bachelor degree has not been mandatory to achieve the position of 
Minister of Economy; of the 13 most renowned ministers in the last fifty years, six had a bachelor's degree in economy (Table I). Similarly, the Bachelor degree in Economics has not been mandatory to occupy the office of Secretary of the Treasury in the United States. Among the 12 who held this position since 1972, six had degrees in other areas: law, engineering, sociology and linguistics. Other characteristics related to political competence are also considered when selecting candidates for this function.

TABLE I

Brazilian Treasury Ministers with no academic formation in Economics who have achieved significant public projection.

\begin{tabular}{|c|c|}
\hline Dilson Domingos Funaro & $1985-1987$ \\
\hline Fernando Henrique Cardoso & $1993-1994$ \\
\hline Maílson Ferreira da Nóbrega & $1988-1990$ \\
\hline Marcílio Marques Moreira & $1991-1992$ \\
\hline Mário Henrique Simonsen & $1974-1979$ \\
\hline Rubens Ricupero & $1994-1994$ \\
\hline
\end{tabular}

The opposite exercise is to consider distinguished economists who played an important role in decisions with national repercussions and to question how important their academic specialty was. Table II lists 20 Brazilian economists selected according to their past and recent presence in the media and on the internet. All have $\mathrm{PhD}$ or an equivalent title in Economics; 11 of them obtained their $\mathrm{PhD}$ from American or European universities. Although they initially had intense academic experience, most of them developed their careers in politics or business. They have undoubtedly been important in the political and economic indoctrination of the business community and the middle class. We may ask how we could identify in them a theoretical basis for their knowledge and judgment. This is not an easily answered question, but some possibilities may be raised, such as (I) success in their activities in public or business administration and (II) peer recognition of their academic competences and theoretical proposals.
Moving outside the Brazilian context and towards an extreme example, Nobel Prize-winning economists have these credentials. Their ideas and recommendations may influence the laymen when they appear in the media (Von Hayek 2012). Nevertheless, equally important is to consider their impact on the community of economists. We may ask how much they care about disseminating their ideas among their peers and to what extent these peers acknowledge the significance of these ideas and proposals. In this case we are dealing with a narrower community of experts who disseminate their ideas and concepts within a more restricted media, comprised of specialized journals and books within the area which will be read and evaluated (cited) by the peers. These citations are registered in international databases that may produce indicators, making it possible to recognize to what extent the community of economists accepts the opinion of a colleague.

One indicator is the so-called h-index (Hirsch 2005), whose precise definition and formula are not relevant at the moment, but that, in short, is a number that reflects two things: production in terms of the number of articles published by a scientist and the number of times that these articles are cited. Two important databases of the h-index are the the ISI-Thomson Reuters and the Publish or Perish Google Scholar. Both provide citations to articles published in journals or books in specific areas of knowledge. The Google database covers a wider universe of documents and ISI is more selective. As an example, in September 2011 the Nobel economist Paul Krugman had an h-index of 65 in Google and of 38 in ISI. It is pertinent to note that publications in the lay media are detected by Google but not by ISI. The h-indexes and corresponding articles from Google may be recovered in table format on the Publish or Perish site, available as open access on the internet. The ISI access requires a license.

How well known are the Brazilian economists shown in Table II according to these two databases? 
We would not expect h-indexes at the level of Nobel Prize winners; in fact the average h-indexes of these economists in Google and ISI are 6.85 and 0.90 , respectively. It reveals an extremely low repercussion of their intellectual contributions to the academic scenario. Moreover, one notices that most of their articles are concentrated in the lay press, indexed in Google. Their presence in the nucleus of the more selective academic economic journals indexed by ISI is rather low. These economists are mostly outside the academic environment, which explains this weakness.

TABLE II

Relevant Brazilian Economists in the last 20 years. h-index values refer to January 2011.

\begin{tabular}{|c|c|c|c|}
\hline ECONOMIST & PhD INSTITUTION & $\begin{array}{c}\text { h-INDEX } \\
\text { GOOGLE SCHOLAR }\end{array}$ & $\begin{array}{c}\text { h-INDEX } \\
\text { ISI-THOMSON-REUTERS }\end{array}$ \\
\hline Affonso Celso Pastore & USP & 15 & 1 \\
\hline André Lara Resende & MIT & 3 & 0 \\
\hline Antonio Delfim Netto & U São Paulo & 3 & 0 \\
\hline Arminio Fraga & Princeton $\mathrm{U}$ & 3 & 1 \\
\hline Carlos Langoni & U Chicago & 8 & 1 \\
\hline Edmar Bacha & Yale U & 21 & 6 \\
\hline Eduardo Gianneti & Cambridge U & 3 & 0 \\
\hline Fernando Cardim de Carvalho & Rutgers U & 11 & 2 \\
\hline Guido Mantega & U São Paulo & 2 & 0 \\
\hline Gustavo Barroso Franco & Harvard U & 11 & 1 \\
\hline Gustavo Loyola & FGV-RJ & 2 & 0 \\
\hline João Paulo dos Reis Velloso & U Fed R Janeiro & 2 & 0 \\
\hline José Eli da Veiga & U Paris & 3 & 0 \\
\hline José Serra & Cornell U & 7 & 1 \\
\hline Luiz Carlos Bresser Pereira & U São Paulo & 23 & 2 \\
\hline Luiz C Mendonça de Barros & U Est Campinas & 2 & 0 \\
\hline
\end{tabular}

Let us now consider an international group of economists with the equivalent attribute of being very influential in the media. For instance, we may examine the list of the 10 most influential economists in the last decade, according to the enquiry made by The Economist Magazine in February 2011 (Avent 2011). Table III shows their names and the h-indexes in Google and ISI, which averaged 42.716.5. The strong contrast between the national and international economists listed in Tables II and III may be explained by the long-standing academic activity of the international economists, several of whom are Nobel Prize winners. Simultaneously, their presence and influence on the political economic scenario are remarkable.
Let us then consider the Brazilian economists who actually belong to the academy. Would they be dedicated to the formation of new doctors and to the intellectual production as an important share of their activities? The best source for these data is the Lattes database for curriculum vitae of the $\mathrm{CNPq}$ (National Council of Science and Technology), which keeps a list of researchers classified by peer committees according to their scientific performance. Level 1-CNPq, the topmost classification, comprises 102 academic investigators in economy (January 2011). It is noteworthy to mention that none of them belong to the list of the most publicly distinguished Brazilian economists indicated in Table II, denoting a dichotomy between academic recognition and 
TABLE III

Most Influential economists in 2001-2010 according to a survey conducted by The Economist in February 2012. h-index values refer to January 2011.

\begin{tabular}{|c|c|c|}
\hline $\begin{array}{c}\text { WORLD'S MOST } \\
\text { INFLUENTIAL } \\
\text { ECONOMISTS }\end{array}$ & $\begin{array}{c}\text { h-INDEX } \\
\text { GOOGLE } \\
\text { SCHOLAR }\end{array}$ & $\begin{array}{c}\text { h-INDEX } \\
\text { ISI-THOMSON- } \\
\text { REUTERS }\end{array}$ \\
\hline Ben Shalom Bernanke & 53 & 20 \\
\hline John Maynard Keynes & 49 & 10 \\
\hline Jeffrey David Sachs & 72 & 24 \\
\hline Hyman Minsky & 29 & 10 \\
\hline Paul Robin Krugman & 65 & 38 \\
\hline Adam Smith 1723-1790 & 0 & 0 \\
\hline Robert Lucas & 65 & 36 \\
\hline Joseph Sitglitz & 114 & 56 \\
\hline Friedrich Hayek & 44 & 4 \\
\hline Alan Greenspan & 32 & 4 \\
\hline Average & $\mathbf{4 2 . 7}$ & $\mathbf{1 6 . 5}$ \\
\hline
\end{tabular}

public distinction in the area of economics in Brazil. Besides, and surprisingly, the h-indexes of these academics average 6.4-1.7, values as h low as those of the non-academic economists listed in Table II.

An additional piece of information may shed some light on the situation. Of the 102 most qualified Brazilian academic economists, $71 \%$ obtained their $\mathrm{PhD}$ in the US or Europe (mostly in UK). This is well above the $33.6 \%$ of the PhD's obtained abroad by the total of 5,300 level 1-CNPq academics in all areas. Their supervisors are economists enjoying international visibility, with high h-indexes averaging 20.5-10.2. The poor indicators of the Brazilian academic economists place them in the 29th world position in publications reported by ISI, as compared to the 13th position for publications in all scientific areas.

What can we conclude from these data? It is relevant to point out that the access to graduate programs in economics is very competitive in the best Brazilian universities. Those who enter are very well prepared to absorb the teaching and are efficiently presented to concepts and theories by proficient professors. The graduates are well equipped to pursue the best post-graduation courses. However the path towards the national post-graduation does not seem to be attractive for students of economics, although they may think that post-graduation route per se is academically attractive and leads to progress in knowledge. From this point of view it is more likely that the Brazilian student feels the lack of intensity in the academic environment of the Economics departments of Brazilian universities. They may realize that there are two other ways to go: one is to pursue a doctoral degree or master's degree in Economics at prestigious international universities, a route that in fact has been taken by many Brazilian economists; another route is to follow the lure of the world business or political activity.

Do the poor scientometrics indicators of Brazilian economists necessarily indicate a lack of valid discussions on economics in the country? This seems to be the case in the national universities but very likely other settings of the think tank type may be a relevant compensation for this lack. These may allow debates that lead to conceptions of advanced knowledge that are not necessarily circulated in the academic environment. The creation of the "Plano Real" (Bacha 1997) might be an example in this context. Therefore, we may predict that intellectually fruitful discussions occur outside the university's walls and that they generate knowledge that is not shared in the world scientific literature. If this alternative is very significant it might explain why US and European universities exert great attraction for Brazilian economics graduate students. They may soon realize that the Brazilian academic environment in this area does not offer the stimulus and challenges found in many other areas of knowledge in national universities.

\section{RESUMO}

$\mathrm{O}$ prestígio internacional de economistas junto à comunidade leiga é significativamente superior ao dos cientistas e acadêmicos de outras áreas do conhecimento. Os economistas brasileiros não são uma exceção. 
Um ponto que chama a atenção é que os economistas de maior prestígio internacional, aqueles que aparecem frequentemente na mídia leiga, são também altamente reputados no ambiente acadêmico. $\mathrm{O}$ prestígio junto aos leigos pode ser medido pela presença na mídia e por consultas à opinião pública, enquanto que o prestígio acadêmico pode ser avaliado através de bases de dados de indicadores de publicações e citações de artigos acadêmicos. Um destes indicadores que se tornou frequentemente utilizado é o índice-h, que mede simultaneamente publicações e citações. Um achado relevante foi que, para economistas internacionais, tanto o prestígio entre os leigos como o entre os acadêmicos são elevados e, aparentemente, mutuamente dependentes.

Entre os economistas nacionais o prestígio entre os leigos não é acompanhado pelo prestígio acadêmico. Este é significativamente baixo, a despeito de que seus currículos frequentemente denotam títulos de doutor por universidades internacionais de excelência. Os dados apesentados indicam uma baixa intensidade de vida acadêmica nas universidades brasileiras.

Palavras-chave: avaliação científica, índice h, economistas brasileiros, prestígio acadêmico, prestígio entre os leigos.

\section{REFERENCES}

AVENT R. 2011. Economics' most influential people. The Economist, 28 Mar, 2011.

BACHA EL. 1997. Plano Real: uma segunda avaliação. In: O Plano Real e outras experiências internacionais de estabilização. IPEA, Escritório da CEPAL no Brasil, p 179-202.

HIRSCH JE. 2005. An index to quantify an individual's scientific research output. Proc. Natl. Acad. Sci. USA, 102: 16569-16572.

Pollock AJ. 2010. Is Economics a Science? J Amer Enterp Inst, 11 June 2010.

VON HAYEK FA. 2012. Banquet Speech. Nobelprize.org. 3 Jun 2012. 